\title{
Economic assessment of grain and ear crops harvesting techniques and technologies in the conditions of the South of Russia
}

\author{
Yury Kastidi ${ }^{*}$ \\ Kuban State Agrarian University named after I.T.Trubilin, Krasnodar, Russia
}

\begin{abstract}
It is statistically proved that in production of grain crops, harvesting is the most labor-and resource-intensive. A comparative technical and economic assessment of technologies for harvesting winter wheat by direct harvesting and combine harvesting was carried out. The calculations performed under the conditions of the model economy of the region proved the economic feasibility of updating the fleet of grain harvesting equipment with machines equipped with combing adapters for harvesting grain crops.
\end{abstract}

In current conditions, in domestic and foreign markets, the main goal of enterprises in the agricultural sector of economy is to maximize profits by producing a reasonable volume of competitive products with minimal production costs. It can be facilitated by the purposeful introduction of modern achievements of science and technology into production.

The basis of effective agricultural production is modern mechanized technologies of cultivation and harvesting of agricultural crops. The amount of direct production costs, the main elements of which are labor, material and monetary costs, depends crucially on their competent combination in one technological process. Also, mechanized technologies and means of mechanization used for their implementation are important factors that affect the quantitative and qualitative characteristics of the products produced [2].

Based on the analysis of agricultural enterprises in the South of Russia, we were able to identify and quantify the most resource-intensive groups of mechanized work in field production (Figure 1).

Studies have shown that in the production of field crops, the most expensive are complexes of mechanized harvesting operations, which account for $53 \%$ of all operating costs and $43 \%$ of labor costs.

Among all agricultural crops, the priority in ensuring the country's food security is grain crops, the main of which is winter wheat.

\footnotetext{
*Corresponding author: kastidykubgau@mail.ru
} 


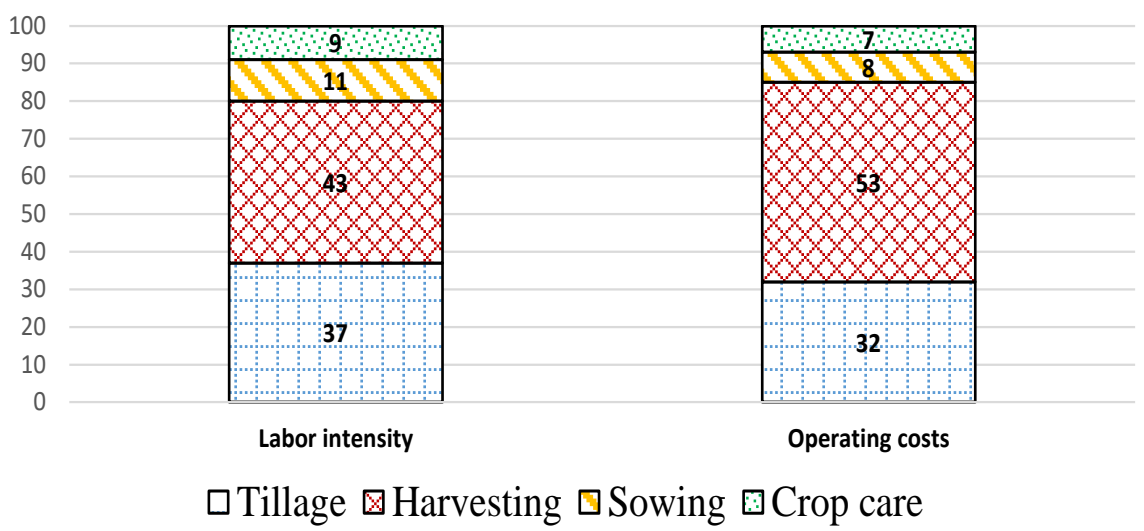

Fig. 1. Cost structure by type of mechanized work in field production

And although in recent years serious progress has been made in increasing the production of grain cereals, state support programs for agriculture at federal and regional levels are being actively implemented, the majority of enterprises in the agricultural sector of the economy still lack equipment and resources to ensure efficient production. At the same time, the most expensive and important element of the material and technical base in the production of grain crops are combine harvesters.

Important issues in the production of grain crops which have not found the solution, are the problems of preventing crop losses and compliance with agricultural regulations for performing mechanized work.

The recommended grain harvest period is 10 days, which avoids significant losses from self-precipitation and a decrease in grain quality. However, not all enterprises are able to perform all harvesting operations in the specified period due to insufficient provision of their material and technical base with harvesting machines [1,3].

The shortage of combine harvesters leads to an increase in the duration of grain harvesting period to 25-30 days. For this reason, in addition to losses due to shedding, there is also a decrease in its crop quality. In addition, due to the lack of equipment, manufacturers deliberately go to an excessive increase in the load of machines to reduce the time of harvesting, which inevitably leads to an increase in the cost of maintaining them in working condition.

Studies have shown that for harvesting grain crops in the recommended time, the combine harvester fleet of Krasnodar Territory should be increased from 3324 units to at least 6000 units. To implement such a project, more than 56 billion rubles of capital investment will be required, which is unaffordable amount for most enterprises in the industry.

The above proves the need for research in the field of justification of introduction of new mechanized technologies for harvesting grain crops in real production. One of the well-known methods of harvesting grain crops, which has not found mass application in Russian agricultural production, is the harvesting of corn by simultaneous grinding, spreading and embedding into soil of the non-grain part of the crop. This method is widely used in the UK and other Western European countries. With the introduction of this technology, the productivity of grain harvesting increases by up to $70 \%$, depending on crop and harvesting conditions. Along with this, there is a $50 \%$ reduction in fuel consumption. The reduction of agricultural terms of harvesting leads to a reduction in the loss of grain 
from shedding, along with this, the quality rates of products increase due to the ability to regulate the content of gluten and protein [3].

To assess the effectiveness of possible areas of replenishment and renewal of the combine harvester fleet in the region based on technologies of direct harvesting and combine harvesting, we calculated operational, technological and technical-economic rates based on quality criteria of harvesting operations.

For the calculation, we chose a typical farm in the central zone of Krasnodar Territory with a total area of 5,000 hectares, of which 3,600 hectares are occupied by winter grain crops. As a basic variant of harvesting operations, the direct combine harvester Acros 530 with the Power Stream 600 harvester is considered, the service life of which is more than 7 years, which corresponds to the average age of combines in the farms of the studied region. As options for performing harvesting operations, we chose direct harvesting with a modern model of the Torum 785 combine harvester with the Power Stream 700 grain harvester and harvesting with the Torum 785 combine harvester with the "OZON" harvester. The initial data for calculations are presented in Table 1.

Table 1. Initial data for the calculation of technical and economic rates of harvesting

\begin{tabular}{|l|c|c|c|}
\hline \multirow{2}{*}{\multicolumn{1}{|c|}{ Parameters }} & \multicolumn{3}{|c|}{ Value of rate } \\
\cline { 2 - 4 } & $\begin{array}{c}\text { Acros 530 + } \\
\text { Power Stream } \\
600\end{array}$ & $\begin{array}{c}\text { Torum 785 + } \\
\text { Power Stream } \\
700\end{array}$ & $\begin{array}{c}\text { Torum 785 } \\
+ \text { «OZON» }\end{array}$ \\
\hline Grain harvesting area, ha & 3600 & 3600 & 3600 \\
\hline Basic crop productivity, c/ha & 68 & 68 & 68 \\
\hline Working speed. km/h & 4,3 & 7,1 & 8,8 \\
\hline Working width of grip, m & 5,7 & 6,7 & 7,7 \\
\hline Coefficient of use of team's time & 0,75 & 0,75 & 0,75 \\
\hline Combine harvester's cost, th.rub. & 6700 & 14500 & 18900 \\
\hline Specific fuel consumption, kg/ha & 14,1 & 10,3 & 8,9 \\
\hline Grain losses for a combine harvester, \% & 4,1 & 1,6 & 1,1 \\
\hline Grain grinding, \% & 5 & 1,3 & 0,8 \\
\hline Clogging of grain heap, \% & 4,1 & 0,73 & 0,6 \\
\hline
\end{tabular}

The data presented in the table show that the technical, operational and price characteristics of harvesting machines for the considered harvesting technologies vary in significant ranges. In Table 2, we have calculated the operating costs for combine harvesting of grain crops.

Table 2. Operating costs for harvesting grain crops with present technologies

\begin{tabular}{|l|c|c|c|}
\hline \multirow{2}{*}{ Parameters } & \multicolumn{3}{|c|}{ Value of rate } \\
\cline { 2 - 4 } & $\begin{array}{l}\text { Acros 530 + } \\
\text { Power Stream 600 }\end{array}$ & $\begin{array}{l}\text { Torum 785 + } \\
\text { PowerStream 700 }\end{array}$ & $\begin{array}{l}\text { Torum 785 + } \\
\text { «OZON» }\end{array}$ \\
\hline Combine harvester's cost, th.rub. & 6700 & 14500 & 18900 \\
\hline Operating costs, rub / ha & 5105 & 2933 & 2446 \\
\hline including: & & & 183 \\
\hline Labor payment & 506 & 261 & 1063 \\
\hline depreciation & 1519 & 1161 & 744 \\
\hline repairs and maintenance & 2278 & 929 & 450 \\
\hline fuel & 783 & 572 & 7 \\
\hline other costs & 20 & 10 & 8806 \\
\hline Total operating costs, th.rub. & 18378 & 10558 & \\
\hline
\end{tabular}


From the data presented in the table, it can be seen that the operating costs for harvesting grain crops in present options differ significantly. If under the basic technology they amount to 5.1 th. rub./ha, then under the combine weight they are reduced to 2.4 th. rub. / ha.

In addition to operating costs, the economic performance of harvesting operations is significantly affected by the amount of grain losses behind the combine harvester, the degree of grain grinding and the level of contamination of the grain pile. The first parameter determines the volume of products received, and the second and third reduce the quality of the grain received and, therefore, are directly related to the price of its sale..

In Table 3, we have calculated the cost of expected crop losses when harvesting wheat by the present technological methods.

Table 3. Parameters of produce losses due to quality rates of harvesting operations.

\begin{tabular}{|l|c|c|c|}
\hline \multirow{2}{*}{ Parameters } & \multicolumn{3}{|c|}{ Value of rate } \\
\cline { 2 - 4 } & $\begin{array}{c}\text { Acros 530 + } \\
\text { PowerStream } \\
600\end{array}$ & $\begin{array}{c}\text { Torum 785 + } \\
\text { PowerStream } \\
700\end{array}$ & $\begin{array}{c}\text { Torum 785 + } \\
\text { «OZON» }\end{array}$ \\
\hline Loss of grain behind the combine, q & 9547 & 4406 & 2693 \\
\hline Lost grain cost, th.rub. & 11457 & 5288 & 3231 \\
\hline Crushed grain received, \% & 11750 & 3182 & 1224 \\
\hline $\begin{array}{l}\text { Amount of losses from crushing grain, } \\
\text { th.rub. }\end{array}$ & 5194 & 1407 & 541 \\
\hline $\begin{array}{l}\text { Additional costs due to clogging of the } \\
\text { grain heap, th.rub. }\end{array}$ & 3327 & 592 & 487 \\
\hline $\begin{array}{l}\text { Total losses from poor-quality cleaning, } \\
\text { th.rub. }\end{array}$ & 19978 & 7287 & 4259 \\
\hline
\end{tabular}

Calculations have shown that grain losses from the quality parameters of harvesting under the present technologies will differ significantly. With the basic technology, they amount to 19.9 million rubles, and with the combine harvesting weight only 4.3 million rubles.

When calculating the effectiveness of the technologies under study, we considered a scenario in which the company will use its own funds to purchase equipment. The lifetime of purchased harvesting equipment is 10 years, and the discount rate is $10 \%$.

The performance parameters for updating the combine harvesting fleet based on the traditional harvesting technology and the proposed technology of harvesting are shown in Table 4.

The calculations performed on the model farm showed that when updating the combine harvesting fleet with equipment for traditional harvesting technology, it is necessary to purchase 12 harvesting machines for the amount of 174 million rubles, while for performing the same work with the use of a combine harvester, the need for equipment is reduced to 7 units for the amount of 132.3 million rubles.

Along with the reduction of initial costs for the purchase of equipment, operating costs and produce losses during the harvesting process are significantly reduced. When updating the combine harvesting fleet of the model farm with equipment for traditional technology, the annual effect will amount to 20.5 million rubles, while when using a combine weight, it increases to 25.3 million rubles. 
Table 4. Efficiency of present harvesting technologies.

\begin{tabular}{|c|c|c|c|}
\hline \multirow[b]{2}{*}{ Parameters } & \multicolumn{3}{|c|}{ Value of rate } \\
\hline & $\begin{array}{l}\text { Acros } 530+ \\
\text { PowerStream } 600\end{array}$ & $\begin{array}{l}\text { Torum } 785+ \\
\text { PowerStream } 700\end{array}$ & $\begin{array}{l}\text { Torum } 785+ \\
\text { «OZON» }\end{array}$ \\
\hline $\begin{array}{l}\text { Combine harvesters for harvesting in } \\
\text { the agrotechnical period, units }\end{array}$ & 20 & 12 & 7 \\
\hline $\begin{array}{l}\text { Cost of the combine harvester fleet, } \\
\text { million rubles }\end{array}$ & 134 & 174 & 132,3 \\
\hline Operational costs, million rubles & 18,4 & 10,6 & 8,8 \\
\hline $\begin{array}{l}\text { Cost of crop losses from poor-quality } \\
\text { harvesting, million rubles }\end{array}$ & 20,0 & 7,3 & 4,3 \\
\hline $\begin{array}{l}\text { Required capital investments, taking } \\
\text { into account the deduction of part of } \\
\text { the cost of basic harvesters, million } \\
\text { rubles. }\end{array}$ & & 120,4 & 78,7 \\
\hline $\begin{array}{l}\text { Expected economic effect, million } \\
\text { rubles. }\end{array}$ & & 20,5 & 25,3 \\
\hline Net discounted income, rub. million & & 18,2 & 92,3 \\
\hline Internal rate of return, \% & & 14,4 & 45,8 \\
\hline Discounted payback period, years & & 8 & 3,5 \\
\hline
\end{tabular}

The obtained dynamic parameters of the efficiency of investments in the renewal of the combine harvesting fleet of the model farm showed the significant advantages of the combine harvester over the traditional harvesting technology and proved the feasibility of the widespread use of combine harvester technologies in the harvesting of grain crops at the enterprises of the region.

\section{References}

1. Bershitsky Yu.I. Economic justification of the nomenclature and quantitative composition of the combine harvesting fleet of agricultural organizations / Yu. I. Bershitsky, K. E. Tyupakov, N. R. Sayfetdinova, Yu. K. Kastidi, A. R. Sayfetdinov // Economics and entrepreneurship. -2015. -№ 9-1 (62-1). -P. 775-779.

2. Kastidi Yu. K., Krepyshev D.A. Economic efficiency of the provision with agricultural machinery of commodity producers in Krasnodar Territory // Proceedings of Kuban State Agrarian University. 2011. № 28. P. 39-42.

3. Romanenko V.A., Trubilin E.I., Fursov I.B., Papusha S.K., Romanenko A.A., Brusentsov A.A., Kravchenko V.V., Mironov V.I., Konovalov V.I., Belousov S.V. «Agricultural machines» (device, operation, and basic adjustments): manual, Krasnodar: KubSAU, 2014. -212 p. 